\title{
OPTIMALISASI KEBUTUHAN GIZI HARIAN IBU MENYUSUI DENGAN BIAYA MINIMUM MENGGUNAKAN METODE SIMPLEKS
}

\author{
Nina ${ }^{1}$, A. Sahari², Resnawati ${ }^{3}$ \\ 1,2,3Program studi Matematika Jurusan Matematika FMIPA Universitas Tadulako \\ Jalan Sukarno-Hatta Km. 9 Palu 94118, Indonesia \\ ${ }^{1}$ chute_nhina@yahoo.com, 2agus sh@yahoo.com,3335n4w4t1@yahoo.com
}

\begin{abstract}
Optimization of daily nutrient needs lactating mothers need in take much more than ordinary people. Formulation of a balanced diet in the diet of lactating mothers, had to be attention to meet the nutrient sufficiency. In this research will be established optimization model to calculate number foods that meet the daily nutrient requirement with minimum costusing the simpleks method. Simpleks method is algebra the solution procedure of the most widely used for linear programming problems. From the results obtained by the model optimization for the first 6 months $Z=9 x_{1}+15 x_{2}+9 x_{3}+5 x_{4}+12 x_{5}+23 x_{6}$ and for the second 6 months $Z=9 x_{1}+10 x_{2}+6 x_{3}+5 x_{4}+$ $15 x_{5}+23 x_{6}$. With the combination of optimally food for the first 6 months is the case of one, namely: rice 89 grams, yellow tail fish 53 grams, spinach 43 grams, peanuts 2 grams and milk SGM 17 grams. The total cost is Rp 2.500, - per meal. While the combination of foods that are optimally for the second 6 months is the four case, namely: rice 32 grams, soybean 0.2 grams, cassava leaves 21 grams, peanuts 75 grams and milk SGM 17 grams. The total cost is $\mathrm{Rp} 2.000$, - per meal. The combination of these foods produce more cheaply than the pattern of daily menu based on the nutrient content for lactating mothers.
\end{abstract}

\section{Keyword $\quad$ : Lactating Mothers, Optimalization, Simpleks Method, The Need Number Nutrient}

\section{ABSTRAK}

Optimalisasi kebutuhan gizi harian ibu menyusui membutuhkan asupan yang jauh lebih banyak dibanding dengan orang biasa.Penyusunan menu seimbang dalam pola makan ibu menyusui menjadi hal yang perlu diperhatikan untuk memenuhi kecukupan gizinya. Dalam penelitian ini akan dibentuk model optimalisasi untuk menghitung jumlah bahan makanan yang memenuhi persyaratan gizi harian dengan biaya minimum menggunakan metode simpleks. Metode simpleks adalah prosedur sosuli aljabar yang paling banyak digunakan untuk masalah program linier. Dari hasil penelitian diperoleh model optimalisasi untuk 6 bulan pertama $Z=9 x_{1}+15 x_{2}+9 x_{3}+5 x_{4}+$ $12 x_{5}+23 x_{6}$ dan untuk 6 bulan kedua $Z=9 x_{1}+10 x_{2}+6 x_{3}+5 x_{4}+15 x_{5}+23 x_{6}$. Dengan kombinasi makanan yang optimal untuk 6 bulan pertama adalah pada kasus satu yaitu : beras 89 gram, ikan ekor kuning 53 gram, bayam 43 gram, kacang tanah 2 gram dan susu SGM 17 gram. Total biaya yang dikeluarkan adalah Rp 2.500,per sekali makan. Sedangkan kombinasi makanan yang optimal untuk 6 bulan kedua adalah pada kasus empat yaitu : beras 32 gram, tempe 0,2 gram, daun singkong 21 gram, kacang tanah 75 gram dan susu SGM 17 gram. 
Total biaya yang dikeluarkan adalah Rp 2,000,- per sekali makan. Kombinasi makanan ini menghasilkan biaya yang lebih murah dibandingkan pola menu sehari berdasarkan kandungan gizi untuk ibu menyusui.

Kata Kunci : Angka Kecukupan Gizi, Ibu Menyusui , Metode Simpleks, Optimalisasi

\section{Pendahuluan}

Gizi ibu menyusui adalah makanan sehat selain obat yang mengandung protein, lemak, mineral, air dan karbohidrat yang dibutuhkan oleh ibu menyusui dalam jumlah tertentu selama menyusui[13]. bu menyusui memiliki kebutuhan yang banyak akan asupan gizi yang terkandung di dalam setiap makanan yang di konsumsinya dengan memperhatikan kebutuhan yang diperlukan oleh tubuhnya, sehingga dengan demikian pola makannya akan lebih diperhatikan melalui penyusunan menu seimbang yang dianjurkan dalam pemenuhan kecukupan gizinya[10].

Gizi pada ibu menyusui sangat erat kaitannya dengan produksi air susu yang sangat dibutuhkan untuk tumbuh kembang bayi. Bila pemberian air susu ibu (ASI) berhasil baik, maka berat badan bayi akan meningkat, integritas kulit baik, serta kebiasaan makan yang memuaskan. Kebutuhan gizi pada ibu nifas terutama bila menyusui akan meningkat $25 \%$, karena berguna untuk proses kesembuhan setelah melahirkan dan untuk memproduksi air susu ibu (ASI) yang cukup untuk menyehatkan bayi[2].

Program linier sebagai suatu teknik analisis kuantitatif, merupakan model matematika yang dapat diterapkan dalam pengambilan keputusan yang telah ditentukan. Dalam permasalahan kandungan nutrisi dari sejumlah makan yang berbeda-beda ini, program linier juga dapat digunakan untuk mencapai nilai optimal, yakni dapat membantu menentukan biaya termurah dan komposisi makanan yang optimal bagi ibu menyusui dengan tetap memenuhi kebutuhan nutrisi bayi yang menyusui dengan menggunakan metode simpleks. Penyelesaian yang diimplementasikan dengan menggunakan program aplikasi TORA (Temporary Routing Algotihm) ${ }^{[6]}$.

\section{METODE PENELITIAN}

\subsection{Studi Pustaka}

Melakukan studi pustaka dengan mengumpulkan materi dari berbagai sumber seperti buku, jurnal dan internet.

\subsection{Tahap Identifikasi}

Tahap identifikasi meliputi penentuan tujuan penelitian, survey pendahuluan, tinjauan pustaka, identifikasi metode analisis dan identifikasi sampel penelitian serta merumuskan masalah yang akan diteliti. 


\subsection{Mengumpulkan data}

Adapun data yang digunakan dalam penelitian ini adalah data primer dan data sekunder. Data primer diperoleh langsung dari survei harga bahan makanan di pasar, sedangkan data sekunder berupa daftar komposisi bahan makanan yang diperoleh dari Badan Ketahanan Pangan Daerah Provinsi Sulawesi Tengah dan Angka Kecukupan Gizi (AKG) Ibu Menyusui.

\subsection{Model Program Linier}

Di dalam menyusun model program linier, [11] mengungkapkan langkah-langkah yang dilakukan adalah mengidentifikasi masalah, menetapkan tujuan dan membentuk formulasi model matematika yang meliputi tiga tahap, yakni:

1. Menentukan variabel keputusan.

2. Membentuk fungsi tujuan yang ditunjukkan sebagai suatu hubungan linier dari variabel keputusan.

3. Menentukan semua kendala masalah tersebut dan mengekspresikan dalam persamaan atau pertidaksamaan yang juga merupakan hubungan linier dari variabel keputusan yang mencerminkan keterbatasan sumber daya masalah itu[3].

Adapun bentuk baku yang diperoleh dari persoalan linier dirumuskan sebagai fungsi kendala berikut :

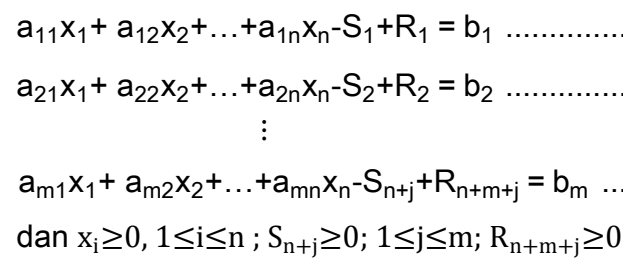

Dimana $S_{n+j}$ adalah variabel pengetat yang menunjukkan suatu kelebihan sumber daya di atas keperluannya dan $R_{n+m+j}$ sebagai variabel semu yang digunakan dalam penyelesaian masalah [7].

\subsection{Menentukan Fungsi Tujuan}

Fungsi tujuan yang diinginkan adalah untuk mendapatkan model optimalisasi yang dapat digunakan untuk memenuhi persyaratan gizi harian ibu menyusui dengan biaya minimum menggunakan metode simpleks dan memperoleh jumlah bahan makanan untuk memenuhi persyaratan gizi harian ibu menyusui dengan biaya minimum menggunakan metode simpleks ${ }^{[9]}$. 


\subsection{Menentukan Fungsi Pembatas dari Fungsi Tujuan}

1. Angka kecukupan gizi yang dianjurkan Badan Ketahanan Pangan Daerah Provinsi Sulawesi Tengah yang menjadi batasan kebutuhan gizi.

2. Bahan makanan yang disajikan dalam sehari yaitu menu makanan gizi seimbang yang dibuat dalam empat kombinasi bahan makanan adalah sebagai berikut[i]:
a. Beras, ikan ekor kuning, bayam, pepaya, kacang tanah dan susu SGM.
b. Beras, telur ayam, wortel, pisang, kacang tanah dan susu SGM.
c. Beras, tahu, daun kelor, jeruk manis, kacang tanah dan susu SGM.
d. Beras, tempe, daun singkong, semangka, kacang tanah dan susu SGM.

3. Daftar harga bahan makanan hasil survei wawancara langsung, berlaku pada bulan november tahun 2014 .

\subsection{Menyelesaikan Model Dengan Menggunakan TORA}

Data yang telah dikumpulkan akan dianalisa menggunakan metode simpleks sesuai dengan kendala-kendala yang dihadapi dan tujuan yang akan dicapai. Asumsi yang digunakan pada pembuatan modelnya adalah kandungan gizi masing-masing bahan tetap ${ }^{[1]}$. Adapun langkah - langkah analisa data adalah sebagai berikut :

1. Menyusun fungsi tujuan, yakni meminimumkan biaya pengeluaran untuk pembelian makanan dengan kandungan gizi yang tetap memenuhi syarat kecukupan gizi ibu menyusui.

Minimumkan $Z=c_{1} x_{1}+c_{2} x_{2}+\cdots+c_{n} x_{n}$

2. Menyusun fungsi kendala atau batasan variabel dan parameter model yang akan digunakan. Fungsi kendala atau batasan:

$$
\begin{gathered}
a_{11} x_{1}+a_{12} x_{2}+\cdots+a_{1 n} x_{n} \geq b_{1} \\
a_{21} x_{1}+a_{22} x_{2}+\cdots+a_{2 n} x_{n} \geq b_{2} \cdots \\
\vdots \\
a_{m 1} x_{1}+a_{m 2} x_{2}+\cdots+a_{m n} x_{n} \geq b_{m} \\
x_{i} \geq 0, x_{2} \geq 0, \ldots, x_{n} \geq 0,1 \leq i \leq n
\end{gathered}
$$

dimana :

$x_{i}=$ jumlah makanan $i, i=1,2,3, \ldots n$

$a_{i}=$ koefisien dari $x_{i}$, yaitu nilai gizi dari bahan makanan $i$.

$b_{i}=$ jumlah kecukupan gizi bahan makanan $i$ yang dibutuhkan ibu menyusui.

3. Merancang data kedalam model matematika dalam bentuk program linear.

4. Memasukkan data yang telah dimodelkan ke dalam program TORA.

5. Mendapatkan solusi optimal. 
Penyelesaian masalah pengoptimalan kandungan gizi yang dikonsumsi dengan biaya minimum ini, penulis menggunakan program TORA ${ }^{[12]}$.

\subsection{Tahap Kesimpulan}

Tahap terakhir dalam penelitian adalah menarik kesimpulan berdasarkan hasil analisis serta saran bagi penelitian lebih lanjut.

\section{Hasil Dan Pembahasan}

\subsection{Hasil Penelitian}

Data yang diperlukan dalam penelitian ini yaitu komposisi kandungan zat gizi bahan makanan, angka kecukupan giziharianibu menyusui dan harga bahan makanan.

Tabel 1 : Daftar Kandungan Zat Gizi (Per 100 gr BDD)

\begin{tabular}{|l|l|c|c|c|c|c|c|c|c|}
\hline No. & \multicolumn{1}{|c|}{$\begin{array}{c}\text { Nama Bahan } \\
\text { Makanan }\end{array}$} & $\begin{array}{c}\text { Energi } \\
(\mathrm{kkal})\end{array}$ & $\begin{array}{c}\text { Protein } \\
(\mathrm{gr})\end{array}$ & $\begin{array}{c}\text { Lemak } \\
(\mathrm{gr})\end{array}$ & $\begin{array}{c}\text { Karbohidrat } \\
(\mathrm{gr})\end{array}$ & $\begin{array}{c}\text { Kalsium } \\
(\mathrm{mg})\end{array}$ & $\begin{array}{c}\text { Besi } \\
(\mathrm{mg})\end{array}$ & $\begin{array}{c}\text { Vit A } \\
(\mathrm{mg})\end{array}$ & $\begin{array}{c}\text { Vit C } \\
(\mathrm{mg})\end{array}$ \\
\hline 1 & Beras & 360 & 6.8 & 0.7 & 78.9 & 6 & 0.8 & 0 & 0 \\
\hline 2 & Ikan Ekor Kuning & 113 & 17.0 & 4.5 & 0 & 20 & 1 & 47 & 0 \\
\hline 3 & Telur Ayam & 162 & 12.8 & 11.5 & 0.7 & 54 & 2.7 & 309 & 0 \\
\hline 4 & Tahu & 68 & 7.8 & 4.6 & 1.6 & 124 & 0 & 0 & 0 \\
\hline 5 & Tempe & 149 & 18.3 & 4 & 12.7 & 129 & 10 & 6 & 0 \\
\hline 6 & Bayam & 36 & 3.5 & 0.5 & 6.5 & 267 & 3.9 & 914 & 80 \\
\hline 7 & Wortel & 42 & 1.2 & 0.3 & 9.3 & 39 & 0.8 & 1800 & 6 \\
\hline 8 & Daun Singkong & 73 & 6.8 & 1.2 & 13 & 165 & 2 & 1650 & 275 \\
\hline 9 & Daun Kelor & 82 & 6.7 & 1.7 & 14.3 & 44 & 70 & 855 & 22 \\
\hline 10 & Pepaya & 46 & 0.5 & 0 & 12.2 & 23 & 1.7 & 56 & 78 \\
\hline 11 & Pisang & 120 & 10.2 & 0.2 & 31.8 & 10 & 0.8 & 139 & 10 \\
\hline 12 & Jeruk Manis & 45 & 0.9 & 0.2 & 11.2 & 33 & 0.4 & 29 & 49 \\
\hline 13 & Semangka & 28 & 0.5 & 0.2 & 6.9 & 7 & 0.2 & 91 & 6 \\
\hline 14 & Kacang Tanah & 452 & 25.3 & 42.8 & 21.1 & 58 & 1.3 & 0 & 3 \\
\hline 15 & Susu SGM & 336 & 8.2 & 10 & 55 & 275 & 0.2 & 175 & 1 \\
\hline
\end{tabular}

Sumber : badan Ketahanan Pangan Daerah Provinsi Sulawesi Tengah, Tahun 2014

Tabel 2 : Daftar Angka Kecukupan Gizi (AKG) Ibu Menyusui

\begin{tabular}{|l|c|c|}
\hline \multirow{2}{*}{ Zat Gizi } & \multicolumn{2}{|c|}{ AKG lbu Menyusui } \\
\cline { 2 - 3 } & $\begin{array}{c}6 \text { bulan pertama } \\
\text { (usia bayi 0-6 bulan) }\end{array}$ & $\begin{array}{c}6 \text { bulan Kedua } \\
\text { (usia bayi 7-12 bulan) }\end{array}$ \\
\hline Energi (kal) & +330 kal & +400 kal \\
\hline
\end{tabular}




\begin{tabular}{|l|c|c|}
\hline Protein (gr) & $+17 \mathrm{gr}$ & $+17 \mathrm{gr}$ \\
\hline Lemak (gr) & $+11 \mathrm{gr}$ & $+13 \mathrm{gr}$ \\
\hline Karbohidrat (gr) & $+45 \mathrm{gr}$ & $+55 \mathrm{gr}$ \\
\hline Kalsium (mg) & $+400 \mathrm{mg}$ & $+400 \mathrm{mg}$ \\
\hline Besi (mg) & $+2 \mathrm{mg}$ & $+2 \mathrm{mg}$ \\
\hline Vitamin A (mg) & $+350 \mathrm{mg}$ & $+350 \mathrm{mg}$ \\
\hline Vitamin C (mg) & $+25 \mathrm{mg}$ & $+10 \mathrm{mg}$ \\
\hline
\end{tabular}

Sumber : Badan Ketahanan Pangan Daerah Provinsi Sulawesi Tengah, Tahun 2014

Tabel 3 : Daftar Harga Bahan Makanan di Pasar Inpres Palu

\begin{tabular}{|c|l|c|c|}
\hline No & \multicolumn{1}{|c|}{ Bahan Makanan } & Harga $(\mathrm{Rp} / \mathrm{Kg})$ & Harga (Rp/gr) \\
\hline 1. & Beras & 9000 & 15 \\
\hline 2. & Ikan ekor kuning & 15000 & 37 \\
\hline 3. & Telur ayam & 37000 & 5 \\
\hline 4. & Tahu & 5000 & 10 \\
\hline 5. & Tempe & 10000 & 9 \\
\hline 6. & Bayam & 9000 & 12 \\
\hline 7. & Wortel & 12000 & 6 \\
\hline 8. & Daun singkong & 6000 & 7 \\
\hline 9. & Daun kelor & 7000 & 5 \\
\hline 10. & Pepaya & 5000 & 10 \\
\hline 11. & Pisang & 10000 & 5 \\
\hline 12. & Semangka & 5000 & 8 \\
\hline 13. & Jeruk manis & 8000 & 15 \\
\hline 14. & Kacang tanah & 15000 & 23 \\
\hline 15. & Susu SGM & 23000 & \\
\hline
\end{tabular}

Sumber : Survei Mandiri Tanggal 12 November 2014, Pasar Inpres Palu

\subsection{Model Program Linier Dalam Gizi Makanan}

Empat kasus kombinasi dari menu makanan gizi seimbang yang dibentuk adalah sebagai berikut :

1. Beras, ikan ekor kuning, daun bayam, pepaya, kacang tanah dan susu SGM.

2. Beras, telur ayam, wortel, pisang, kacang tanah dan susu SGM.

3. Beras, tahu, daun kelor, jeruk manis, kacang tanah dan susu SGM.

4. Beras, tempe, daun singkong, semangka, kacang tanah dan susu SGM. 


\subsection{Variabel Keputusan $\left(x_{j}\right)$}

Dalam menyatakan variabel keputusan dinyatakan sebagai berikut :

$x_{1}=$ Jenis makanan pokok dalam kombinasi makanan (Beras)

$x_{2}=$ Jenis lauk pauk dalam kombinasi makanan (Ikan ekor kuning, telur ayam, tahu dan tempe)

$x_{3}=$ Jenis sayur dalam kombinasi makanan (Daun bayam, wortel, daun kelor dan daun singkong)

$x_{4}=$ Jenis buah dalam kombinasi makanan (Pepaya, pisang, jeruk manis dan semangka)

$x_{5}=$ Kacang tanah dalam kombinasi makanan(Kacang tanah)

$x_{6}=$ Susu dalam kombinasi makanan (Susu SGM)

Dari variabel tersebut dan keempat kombinasi bahan makanan dari menu makanan gizi seimbang, akan dihitung kecukupan gizi harian dengan biaya minimum pada ibu menyusui dengan ketentuan aturan kebutuhan gizi yang telah ditetapkan oleh angka kecukupan gizi (AKG).

\subsection{Model Kombinasi Makanan Ibu Menyusui}

\subsubsection{Kombinasi Makanan untuk 6 Bulan Pertama (Usia Bayi 0-6 Bulan)}

Model matematika yang telah dibuat pada kombinasi bahan makanan untuk 6 bulan pertama (usia bayi 0-6 bulan), diubah kedalam bentuk standar untuk masingmasing kasusnya, yaknid engan menambahkan perubahan pengetat (slack variable) yaitu $\mathrm{S}_{j}$ dengan $j=1,2, \ldots, 8$ dan peubah semu (artificial variable) yaitu $\mathrm{R}_{k}$ dengan $k$ $=1,2, \ldots, 8$. Sehingga kendala ini sudah berubah menjadi susunan persamaan linier $\sum_{j}^{n} a_{i j} x_{j}-S_{j}+R_{k}=b_{i}$. Dengan demikian, diperoleh fungsi tujuan dan fungsi kendalanya.

\section{a. Kasus Satu}

Bentuk standar yang dihasilkan adalah sebagai berikut :

Minimumkan $: Z=9 x_{1}+15 x_{2}+9 x_{3}+5 x_{4}+15 x_{5}+23 x_{6}$

\section{Kendala :}

$\begin{array}{ll}3,6(89)+1,09(53)+0,51(43)+0,46(0)+4,52(2)+0,65(17)-S_{1}+R_{1} & =330 \\ 0,068(89)+0,17(53)+0,046(43)+0,005(0)+25,3(2)+1,1(17)-S_{2}+R_{2} & =17 \\ 7,0(89)+0,04(53)+0,005(43)+0,428(2)+0,035(17)-S_{3}+R_{3} & =11 \\ 0,789(89)+0,1(43)+0,112(0)+0,211(2)+7,7(17)-S_{4}+R_{4} & =45 \\ 0,06(89)+5(53)+3,68(43)+0,23(0)+0,58(2)+0,353(17)-S_{5}+R_{5} & =400 \\ 0,008(89)+0,01(53)+0,022(43)+0,017(0)+0,013(17)-S_{6}+R_{6} & =2 \\ 0,47(53)+8,7(43)+0,56(0)+0,7(17)-S_{7}+R_{7} & =350 \\ 0,8(43)+0,78(0)+0,03(2)+2,7(17)-S_{8}+R_{8} & =25 \\ x_{i}=0, i=1,2,3,4,5,6 . S_{j}=0, j=1,2, \ldots, 8 ; R_{k}=0, \mathrm{k}=1,2, \ldots, 8 . & \end{array}$


Berdasarkan perhitungan menggunakan TORA seperti yang ditunjukkan pada Lampiran 5,dapat diketahui bahwa $x_{1}=89.417 ; x_{2}=53.750 ; x_{3}=43.750 ; x_{4}=0 ; x_{5}=2.000$; $x_{6}=17.000$. Dengan demikian dapat diartikan bahwa dalam kombinasi makanan yang memenuhi persyaratan gizi harian ibu menyusui, dibutuhkan jumlah bahan makanan beras sebanyak 89 gram, ikan ekor kuning sebanyak 53 gram, bayam sebanyak 43 gram, pepaya 0 gram, kacang tanah sebanyak 2 gram dan susu SGM sebanyak 17 gram. Kemudian harga bahan makanan yang dibutuhkan diperoleh dengan memasukkan nilai variabel yang diperoleh ke dalam fungsi tujuan :

$$
Z=9 x_{1}+15 x_{2}+9 x_{3}+5 x_{4}+15 x_{5}+23 x_{6}=2.425
$$

Jadi, harga minimum kombinasi bahan makanan untuk iterasi optimum adalah iterasi 12 dimana diperoleh adalah Rp. 2.425 atau dibulatkan menjadi Rp. 2.500,- untuk sekali makan.

\section{b. Kasus Dua}

Bentuk standar yang dihasilkan adalah sebagai beriut :

Minimumkan : $\mathrm{Z}=9 \mathrm{x}_{1}+37 \mathrm{x}_{2}+12 \mathrm{x}_{3}+10 \mathrm{x}_{4}+15 \mathrm{x}_{5}+23 \mathrm{x}_{6}$

Kendala :

$$
\begin{array}{ll}
3,6(3)+1,62(0)+0,42(19)+1,2(0)+4,52(80)+0,62(17)-S_{1}+R_{1} & =330 \\
0,068(3)+0,128(0)+0,012(19)+0,10(0)+0,253(80)+1,1(17)-S_{2}+R_{2} & =17 \\
7,0(3)+0,115(0)+0,003(19)+0,002(0)+0,428(80)+0,035(17)-S_{3}+R_{3} & =11 \\
0,789(3)+0,007(0)+0,093(19)+0,318(0)+0,211(80)+7,7(17)-S_{4}+R_{4} & =45 \\
0,06(3)+0,54(0)+0,39(19)+0.1(0)+0,58(80)+0,353(17)-S_{5}+R_{5} & =400 \\
0,008(3)+0,027(0)+0,008(19)+8,0(0)+0,013(80)-S_{6}+R_{6} & =2 \\
3,09(0)+18(19)+1,39(0)+0,7(17)-S_{7}+R_{7} & =350 \\
0,06(19)+0,1(0)+0,03(80)+2,7(17)-S_{8}+R_{8} & =25 \\
x_{i}=0, i=1,2,3,4,5,6 . S_{j}=0, j=1,2, \ldots, 8 ; R_{k}=0, k=1,2, \ldots, 8 . &
\end{array}
$$

Berdasarkan perhitungan menggunakan TORA seperti yang ditunjukkan pada Lampiran 5,dapat diketahui bahwa $x_{1}=3.250 ; x_{2}=0 ; x_{3}=19.431 ; x_{4}=0.250 ; x_{5}=80.000$; $x_{6}=17.000$. Dengan demikian dapat diartikan bahwa dalam kombinasi makanan yang memenuhi persyaratan gizi harian ibu menyusui,dibutuhkan jumlah bahan makanan beras sebanyak 3 gram, telur ayam 0 gram, wortel sebanyak 19 gram, pisang sebanyak 0.2 gram, kacang tanah sebanyak 80 gram dan susu SGM sebanyak 17 gram. Kemudian harga bahan makanan yang dibutuhkan diperoleh dengan memasukkan nilai variabel yang diperoleh ke dalam fungsi tujuan :

$$
\mathrm{Z}=9 \mathrm{x}_{1}+37 \mathrm{x}_{2}+12 \mathrm{x}_{3}+10+15 \mathrm{x}_{5}+23 \mathrm{x}_{6}=1.855
$$

Jadi, harga minimum kombinasi bahan makanan untuk iterasi optimum adalah iterasi 13 dimana diperoleh adalah Rp.1.855 atau dibulatkan menjadi Rp. 1.855,- untuk sekali makan. 


\section{c. Kasus Tiga}

Bentuk standar yang dihasilkan adalah sebagai berikut :

Minimumkan : $\mathrm{Z}=9 \mathrm{x}_{1}+5 \mathrm{x}_{2}+7 \mathrm{x}_{3}+8 \mathrm{x}_{4}+15 \mathrm{x}_{5}+23 \mathrm{x}_{6}$

\section{Kendala :}

$$
\begin{array}{ll}
3,6(50)+0,68(0)+0,82(43)+0,45(0)+4,52(45)+0,65(17)-S_{1}+R_{1} & =330 \\
0,068(50)+0,78(0)+0,067(43)+0,009(0)+0,253(45)+1,1(17)-S_{2}+R_{2} & =17 \\
7,0(50)+0,046(0)+0,017(43)+0,002(0)+0,428(45)+0,035(17)-S_{3}+R_{3} & =11 \\
0,789(50)+0,016(0)+0,143(43)+0,112(0)+0,211(45)+7,7(17)-S_{4}+R_{4} & =45 \\
0,06(50)+1,24(0)+4,4(43)+0,33(0)+0,58(45)+0,353(17)-S_{5}+R_{5} & =400 \\
0,008(50)+0,07(43)+4,0(0)+0,01(17)-S_{6}+R_{6} & =2 \\
8,55(43)+0,29(0)+0,7(17)-S_{7}+R_{7} & =350 \\
2,2(43)+0,49(0)+0,03(45)+2,7(17)-S_{8}+R_{8} & =25 \\
x_{i}=0, i=1,2,3,4,5,6 . S_{j}=0, j=1,2, \ldots, 8 ; R_{k}=0, k=1,2, \ldots, 8 . &
\end{array}
$$

Berdasarkan perhitungan menggunakan TORA seperti yang ditunjukkan pada Lampiran 5,dapat diketahui bahwa $x_{1}=50.000 ; x_{2}=0 ; x_{3}=43.750 ; x_{4}=0.500 ; x_{5}=45.000$; $x_{6}=17.000$. Dengan demikian dapat diartikan bahwa dalam kombinasi makanan yang memenuhi persyaratan gizi harian ibu menyusui,dibutuhkan jumlah bahan makanan beras sebanyak 50 gram, tahu 0 gram, daun kelor 43 gram, jeruk manis sebanyak 0,5 gram, kacang tanah sebanyak 45 gram dan susu SGM 17 gram. Kemudian harga bahan makanan yang dibutuhkan diperoleh dengan memasukkan nilai variabel yang diperoleh ke dalam fungsi tujuan :

$\mathrm{Z}=9 \mathrm{x}_{1}+5 \mathrm{x}_{2}+7 \mathrm{x}_{3}+8 \mathrm{x}_{4}+15 \mathrm{x}_{5}+23 \mathrm{x}_{6}=1.826$

Jadi, harga minimum kombinasi bahan makanan untuk iterasi optimum adalah iterasi 12 dimana diperoleh adalah Rp.1.826 atau dibulatkan menjadi Rp. 1.800,- untuk sekali makan.

\section{d. Kasus Empat}

Bentuk standar yang dihasilkan adalah sebagai berikut :

Minimumkan $\mathrm{Z}=9 \mathrm{x}_{1}+10 \mathrm{x}_{2}+6 \mathrm{x}_{3}+5 \mathrm{x}_{4}+15 \mathrm{x}_{5}+23 \mathrm{x}_{6}$ :

\section{Kendala :}

$$
\begin{array}{ll}
3,6(8)+3,28(0)+0,73(21)+0,28(0)+4,52(75)+0,65(17)-S_{1}+R_{1} & =330 \\
0,068(8)+0,184(0)+0,068(21)+0,005(0)+0,253(75)+1,1(17)-S_{2}+R_{2} & =17 \\
7,0(8)+0,005(0)+0,012(21)+0,002(0)+0,428(75)+0,035(17)-S_{3}+R_{3} & =11 \\
0,789(8)+0,1(0)+0,13(21)+0,065(0)+0,211(75)+7,7(17)-S_{4}+R_{4} & =45 \\
0,06(8)+3,68(0)+1,65(21)+0,07(0)+5,8(75)+0,353(17)-S_{5}+R_{5} & =400 \\
0,008(8)+0,022(0)+0,02(21)+2,0(0)+0,013(75)-S_{6}+R_{6} & =2 \\
8,7(0)+16,5(21)+0,91(0)+0,7(17)-S_{7}+R_{7} & =350 \\
0,8(0)+0,06(21)+2,7(75)+1,0(17)-S_{8}+R_{8} & =25 \\
x_{i}=0, i=1,2,3,4,5,6 . S_{j}=0, j=1,2, \ldots, 8 ; R_{k}=0, k=1,2, \ldots, 8 . &
\end{array}
$$

Berdasarkan perhitungan menggunakan TORA seperti yang ditunjukkan pada Lampiran 5, dapat diketahui bahwa $\mathrm{x}_{1}=8.967 ; \mathrm{x}_{2}=0.2000 ; \mathrm{x}_{3}=21.875 ; \mathrm{x}_{4}=0 ; \mathrm{x}_{5}=$ 
75.625; $x_{6}=17.000$. Dengan demikian dapat diartikan bahwa dalam kombinasi makanan yang memenuhi persyaratan gizi harian ibu menyusui,dibutuhkan jumlah bahan makanan beras sebanyak 8 gram, tempe sebanyak 0.2 gram, daun singkong sebanyak 21 gram, semangka 0 gram, kacang tanah sebanyak 75 gram dan susu SGM sebanyak 17 gram. Kemudian harga bahan makanan yang dibutuhkan diperoleh dengan memasukkan nilai variabel yang diperoleh ke dalam fungsi tujuan :

$\mathrm{Z}=9 \mathrm{x}_{1}+10 \mathrm{x}_{2}+6 \mathrm{x}_{3}+5 \mathrm{x}_{4}+15 \mathrm{x}_{5}+23 \mathrm{x}_{6}=1.739$

Jadi, harga minimum kombinasi bahan makanan untuk iterasi optimum adalah iterasi 12 dimana diperolehadalah Rp.1.739 atau dibulatkan menjadi Rp. 1.750,- untuk sekali makan.

\subsubsection{Kombinasi Makanan Untuk 6 Bulan Kedua (Usia Bayi 7-12 Bulan)}

Model matematika yang telah dibuat pada kombinasi bahan makanan untuk 6 bulan kedua (usia bayi 7-12 bulan), diubah kedalam bentuk standar untuk masingmasing kasusnya, yakni dengan menambahkan perubahan pengetat (slack variable) yaitu $S_{j}$ dengan $j=1,2, \ldots, 8$ dan peubah semu (artificial variable) yaitu $\mathrm{R}_{k}$ dengan $k=$ $1,2, \ldots, 8$. Sehingga kendala ini sudah berubah menjadi susunan persamaan linear $\sum_{j}^{n} a_{i j} x_{j}-S_{j}+R_{k}=b_{i}$. Dengan demikian, diperoleh fungsi tujuan dan fungsi kendalanya.

\section{a. Kasus Satu}

Bentuk standar yang dihasilkan adalah sebagai berikut :

Minimumkan $: Z=9 x_{1}+15 x_{2}+9 x_{3}+5 x_{4}+15 x_{5}+23 x_{6}$

Kendala :

$\begin{array}{ll}3,6(112)+1,09(53)+0,51(43)+0,46(0)+4,52(2)+0,65(17)-S_{1}+R_{1} & =400 \\ 0,068(112)+0,17(53)+0,046(43)+0,005(0)+25,3(2)+1,1(17)-S_{2}+R_{2} & =17 \\ 7,0(112)+0,04(53)+0,005(0)+0,428(2)+0,035(17)-S_{3}+R_{3} & =13 \\ 0,789(112)+0,1(43)+0,112(0)+0,211(2)+7,7(17)-S_{4}+R_{4} & =55 \\ 0,06(112)+5(53)+3,68(43)+0,23(0)+0,58(2)+0,353(17)-S_{5}+R_{5} & =400 \\ 0,008(112)+0,01(53)+0,022(43)+0,017(0)+0,013(17)-S_{6}+R_{6} & =2 \\ 0,47(53)+8,7(43)+0,56(0)+0,7(17)-S_{7}+R_{7} & =350 \\ 0,8(43)+0,78(0)+0,03(2)+2,7(17)-S_{8}+R_{8} & =10 \\ x_{i}=0, i=1,2,3,4,5,6 . S_{j}=0, j=1,2, \ldots, 8 ; R_{k}=0, \mathrm{k}=1,2, \ldots, 8 . & \end{array}$

Berdasarkan perhitungan menggunakan TORA seperti yang ditunjukkan pada Lampiran 5, dapat diketahui bahwa $x_{1}=112.750 ; x_{2}=53.750 ; x_{3}=43.750 ; x_{4}=0 ; x_{5}=$ 2.000; $x_{6}=17.000$. Dengan demikian dapat diartikan bahwa dalam kombinasi makanan yang memenuhi persyaratan gizi harian ibu menyusui,dibutuhkan jumlah bahan makanan beras sebanyak 112 gram, ikan ekor kuning sebanyak 53 gram, bayam 
sebanyak 43 gram, pepaya 0 gram, kacang tanah sebanyak 2 gram dan susu SGM sebanyak 17 gram. Kemudian harga bahan makanan yang dibutuhkan diperoleh dengan memasukkan nilai variabel yang diperoleh ke dalam fungsi tujuan : $Z=9 x_{1}+15 x_{2}+9 x_{3}+5 x_{4}+15 x_{5}+23 x_{6}=2.635$ Jadi, harga minimum kombinasi bahan makanan untuk iterasi optimum adalah iterasi 12 dimana diperoleh adalah Rp.2.635 atau dibulatkan menjadi Rp. 2.650,- untuk sekali makan.

b. Kasus dua

Bentuk standar yang dihasilkan adalah sebagai berikut :

Minimumkan $: Z=9 x_{1}+37 x_{2}+12 x_{3}+10 x_{4}+15 x_{5}+23 x_{6}$

Kendala :

$\begin{array}{ll}3,6(26)+1,62(0)+0,42(19)+1,2(0)+4,52(80)+0,62(17)-S_{1}+R_{1} & =400 \\ 0,068(26)+0,128(0)+0,012(19)+0,10(0)+0,253(80)+1,1(17)-S_{2}+R_{2} & =17 \\ 7,0(26)+0,115(0)+0,003(19)+0,002(0)+0,428(80)+0,035(17)-S_{3}+R_{3} & =13 \\ 0,789(26)+0,007(0)+0,093(19)+0,318(0)+0,211(80)+7,7(17)-S_{4}+R_{4} & =55 \\ 0,06(26)+0,54(0)+0,39(19)+0.1(0)+0,58(80)+0,353(17)-S_{5}+R_{5} & =400 \\ 0,008(26)+0,027(0)+0,008(19)+8,0(0)+0,013(80)-S_{6}+R_{6} & =2 \\ 3,09(0)+18(19)+1,39(0)+0,7(17)-S_{7}+R_{7} & =350 \\ 0,06(19)+0,1(0)+0,03(80)+2,7(17)-S_{8}+R_{8} & =10\end{array}$

$\mathrm{x}_{\mathrm{i}}=0, \mathrm{i}=1,2,3,4,5,6$.

$S_{j}=0, j=1,2, \ldots, 8 ; R_{k}=0, k=1,2, \ldots, 8$.

Berdasarkan perhitungan menggunakan TORA seperti yang ditunjukkan pada Lampiran 5,dapat diketahui bahwa $x_{1}=26.583 ; x_{2}=0 ; x_{3}=19.431 ; x_{4}=0.250 ; x_{5}=80.000$; $x_{6}=17.000$. Dengan demikian dapat diartikan bahwa dalam kombinasi makanan yang memenuhi persyaratan gizi harian ibu menyusui,dibutuhkan jumlah bahan makan beras sebanyak 26 gram, telur ayam 0 gram, wortel sebanyak 19 gram, pisang sebanyak 0,2 gram, kacang tanah sebanyak 80 gram dan susu SGM sebanyak 17 gram. Kemudian harga bahan makanan yang dibutuhkan diperoleh dengan memasukkan nilai variabel yang diperoleh ke dalam fungsi tujuan :

$Z=9 x_{1}+37 x_{2}+12 x_{3}+10 x_{4}+15 x_{5}+23 x_{6}=2.065$

Jadi, harga minimum kombinasi bahan makanan untuk iterasi optimum adalah iterasi 13 dimana diperoleh adalah Rp.2.065atau dibulatkan menjadi Rp. 2.000,- untuk sekali makan.

c. Kasus tiga

Bentuk standar yang dihasilkan adalah sebagai berikut :

Minimumkan: $\square \mathrm{Z}=9 \mathrm{x}_{1}+5 \mathrm{x}_{2}+7 \mathrm{x}_{3}+8 \mathrm{x}_{4}+15 \mathrm{x}_{5}+23 \mathrm{x}_{6}$

Kendala :

$3,6(73)+0,68(0)+0,82(43)+0,45(0)+4,52(45)+0,65(17)-S_{1}+R_{1}=400$ 


$$
\begin{array}{ll}
0,068(73)+0,78(0)+0,067(43)+0,009(0)+0,253(45)+1,1(17)-S_{2}+R_{2} & =17 \\
7,0(73)+0,046(0)+0,017(43)+0,002(0)+0,428(45)+0,035(17)-S_{3}+R_{3} & =13 \\
0,789(73)+0,016(0)+0,143(43)+0,112(0)+0,211(45)+7,7(17)-S_{4}+R_{4} & =55 \\
0,06(73)+1,24(0)+4,4(43)+0,33(0)+0,58(45)+0,353(17)-S_{5}+R_{5} & =400 \\
0,008(73)+0,07(43)+4,0(0)+0,01(17)-S_{6}+R_{6} & =2 \\
8,55(43)+0,29(0)+0,7(17)-S_{7}+R_{7} & =350 \\
2,2(43)+0,49(0)+0,03(45)+2,7(17)-S_{8}+R_{8} & =10 \\
x_{i}=0, i=1,2,3,4,5,6 . & \\
S_{j}=0, j=1,2, \ldots, 8 ; R_{k}=0, k=1,2, \ldots, 8 . &
\end{array}
$$

Berdasarkan perhitungan menggunakan TORA seperti yang ditunjukkan pada Lampiran 5, dapat diketahui bahwa $x_{1}=73.333 ; x_{2}=0 ; x_{3}=43.750 ; x_{4}=0.500 ; x_{5}=$ 45.000; $x_{6}=17.000$.Dengan demikian dapat diartikan bahwa dalam kombinasi makanan yang memenuhi persyaratan gizi harian ibu menyusui,dibutuhkan jumlah bahan makanan beras sebanyak 73 gram, tahu 0 gram, daun kelor sebanyak 43 gram, jeruk manis sebanyak 0,5 gram, kacang tanah sebanyak 45 gram dan susu SGM sebanyak 17 gram. Kemudian harga bahan makanan yang dibutuhkan diperoleh dengan memasukkan nilai variabel yang diperoleh ke dalam fungsi tujuan :

$\mathrm{Z}=9 \mathrm{x}_{1}+5 \mathrm{x}_{2}+7 \mathrm{x}_{3}+8 \mathrm{x}_{4}+15 \mathrm{x}_{5}+23 \mathrm{x}_{6}=2.036$

Jadi, harga minimum kombinasi bahan makanan untuk iterasi optimum adalah iterasi 13 dimana diperoleh adalah Rp.2.036 atau dibulatkan menjadi Rp 2.000,- untuk sekali makan.

\section{d. Kasus empat}

Bentuk standar yang dihasilkan adalah sebagai berikut :

Minimumkan $: Z=9 x_{1}+5 x_{2}+3+12 x_{4}+18 x_{5}+12 x_{6}$

Kendala :

$$
\begin{array}{ll}
3,6(32)+3,28(0)+0,73(21)+0,28(0)+4,52(75)+0,65(17)-S_{1}+R_{1} & =400 \\
0,068(32)+0,184(0)+0,068(21)+0,005(0)+0,253(75)+1,1(17)-S_{2}+R_{2} & =17 \\
7,0(32)+0,005(0)+0,012(21)+0,002(0)+0,428(75)+0,035(17)-S_{3}+R_{3} & =13 \\
0,789(32)+0,1(0)+0,13(21)+0,065(0)+0,211(75)+7,7(17)-S_{4}+R_{4} & =55 \\
0,06(32)+3,68(0)+1,65(21)+0,07(0)+5,8(75)+0,353(17)-S_{5}+R_{5} & =400 \\
0,008(32)+0,022(0)+0,02(21)+2,0(0)+0,013(75)-S_{6}+R_{6} & =2 \\
8,7(0)+16,5(21)+0,91(0)+0,7(17)-S_{7}+R_{7} & =350 \\
0,8(0)+0,06(21)+2,7(75)+1,0(17)-S_{8}+R_{8} & =10 \\
x_{i}=0, i=1,2,3,4,5,6 & \\
S_{j}=0, \quad j=1,2, \ldots, 8 ; R_{k}=0, k=1,2, \ldots, 8 . &
\end{array}
$$

Berdasarkan perhitungan menggunakan TORA seperti yang ditunjukkan pada Lampiran 5, dapat diketahui bahwa $x_{1}=32.300 ; x_{2}=0.2000 ; x_{3}=21.875 ; x_{4}=0 ; x_{5}=$ 75.625; $x_{6}=17.000$. Dengan demikian dapat diartikan bahwa dalam kombinasi makanan yang memenuhi persyaratan gizi harian ibu menyusui,dibutuhkan jumlah bahan makanan beras sebanyak 32 gram, tempe sebanyak 0,2 gram, daun singkong 
sebanyak 21 gram, semangka 0 gram, kacang tanah sebanyak 75 gram dan susu SGM sebanyak 17 gram. Kemudian harga bahan makanan yang dibutuhkan diperoleh dengan memasukkan nilai variabel yang diperoleh ke dalam fungsi tujuan : $Z=9 x_{1}+10 x_{2}+6+5 x_{4}+15 x_{5}+23 x_{6}=1.949$ Jadi, harga minimum kombinasi bahan makanan untuk iterasi optimum adalah iterasi 12 dimana diperoleh adalah Rp.1.949 atau dibulatkan menjadi Rp. 2.000,- untuk sekali makan.

\section{Kesimpulan}

Berdasarkan hasil yang didapatkan dalam penelitian ini, maka dapat disimpulkan sebagai berikut :

1. Bentuk formulasi model optimalisasi yang digunakan untuk memenuhi syarat gizi harian dengan biaya minimum pada 6 bulan pertama untuk (usia bayi 0-6 bulan) adalah pada kasus satu dengan model matematika :

$Z=9 x_{1}+15 x_{2}+9 x_{3}+5 x_{4}+15 x_{5}+23 x_{6}$

Sedangkan pada 6 bulan kedua untuk (usia bayi 7-12 bulan) adalah pada kasus empat dengan model matematika :

$$
Z=9 x_{1}+10 x_{2}+6 x_{3}+5 x_{4}+15 x_{5}+23 x_{6}
$$

2. Alternatif kombinasi bahan makanan yang optimal untuk kebutuhan gizi sehari untuk 6 bulan pertama (usia bayi 0-6 bulan) dengan biaya minimum adalah kombinasi makanan pada kasus satu, yaitu: Beras sebanyak 89 gram, ikan ekor kuning sebanyak 53 gram, bayam sebanyak 43 gram, pepaya 0 gram, kacang tanah sebanyak 2 gram dan susu SGM sebanyak 17 gram. Total biaya yang dikeluarkan adalah Rp 2.500,- per sekali makan. Sedangkan, alternatif kombinasi makanan yang optimal untuk 6 bulan kedua (usia bayi 7-12 bulan) adalah kombinasi makanan pada kasus empat, yaitu : Beras sebanyak 32 gram, tempe sebanyak 0,2 gram, daun singkong sebanyak 21 gram, semangka 0 gram, kacang tanah sebanyak 75 gram dan susu SGM sebanyak 17 gram. Total biaya yang dikeluarkan adalah Rp. 2.000,- per sekali makan. Kombinasi makanan ini menghasilkan biaya yang lebih murah dibandingkan pola menu makanan sehari berdasarkan kandungan gizi untuk ibu menyusui.

\section{DAFTAR PUSTAKA}

[1]. Almatsier, S. 2004. Prinsip Dasar IImu Gizi. PT Gramedia Pustaka Utama. Jakarta.

[2]. Ambarwati, R., Eny, dan Wulandari, D. 2009. Asuhan Kebidanan Nifas. Mitra Cendikia Offsetsuha. Jakarta. 
[3]. Aminuddin. 2005. Prinsip-Prinsip Riset Operasi. Erlangga. Jakarta.

[4]. Badan Ketahanan Pangan Daerah Sulawesi Tengah. 2014. Daftar Angka Kecukupan Gizi yang dianjurkan. Palu.

[5]. Badan Ketahanan Pangan Daerah Sulawesi Tengah. 2014. Daftar Kandungan Zat Gizi (per 100 gr BDD). Palu.

[6]. Hamdy, A. T. 1996. Riset Operasi. Lembaga Penerbit Bina Putra Aksara. Jakarta.

[7]. Mulyono, S. 1991. Operation Research. Lembaga Penerbit Fakultas Ekonomi UI. Jakarta.

[8]. Soekirman. 2000. IImu Gizi dan Aplikasinya untuk Keluarga dan masyarakat. Direktorat Jendral Pendidikan Tinggi, Departemen Pendidikan Nasional. Jakarta.

[9]. Subagyo, dkk. 1992. Dasar-dasar Operation Research. Edisi Kedua, BPFE. Yogyakarta.

[10]. Supariasa, et. al. 2002. Penilaian Status Nutrisi. Penerbit Buku Kedokteran EGC. pp:37-121. Jakarta.

[11]. Supranto, J. M. A.. 1983. Linear Programming. Edisi kedua, Lembaga Penerbit Fakultas Ekonomi Universitas Indonesia. Jakarta.

[12]. Sutawidjaja, A.. dan Sudirman. 2005. Program Linear. Penerbit Universitas Negeri Malang (UM PRESS). Malang.

[13]. Tejasari. 2005. Nilai-Gizi Pangan (Edisi Pertama). Graha Ilmu. Yogyakarta. 